\title{
CASE REPORT: RESTORATION OF EDENTULOUS MANDIBLE WITH 4 BOI IMPLANTS IN AN IMMEDIATE LOAD PROCEDURE
}

\author{
Stefan Ihde ${ }^{\mathrm{a}}$, Miroslav Eber ${ }^{\mathrm{b}}$
}

\author{
${ }^{a}$ Zahnärztliche Klinik Gommiswald AG, Dorfplatz 11, Gommiswald, CH-8737, dr.ihde@bluewin.ch \\ ${ }^{b}$ Clinic of Dentistry, Faculty of Medicine, Palacký University, Palackého 12, 77200 Olomouc, Czech Republic \\ e-mail:eber@tunw.upol.cz
}

Received: December 20, 2004; Accepted: December 28, 2004

Key words: BOI implants/Immediate loading/Chewing pattern

Dental implants for insertion from the lateral aspects of the jaw bone have been described repeatedly, since $1972^{12,17}$. Long term results have been reported.

Due to their design, BOI-Implants (basal osseointegration) can be installed even in those cases, where the vertical bone supply is reduced. This applies to the distal areas of the maxilla and the mandible. Furthermore, BOI-implants allow immediate loading as long as a balanced masticatory function can be achieved and maintained ${ }^{18}$. This paper reports on the steps taken to install a full lower bridge in 4 BOI-implants and restoration in a patient with a circular bridge. The bridge was made from CoCr-Alloy and covered with acrylic resin. This treatment technique reduces costs and treatment time by about $50 \%$ compared to conventional techniques.

\section{INTRODUCTION}

A 67 year old, healthy, non-smoking male patient who had been edentulous for approxilately 20 years, had not been wearing any dentures except for the last 2 months. During the last two months he had adapted to the vertical change. The mandible showed the typical signs of long untreated edentulessness: the angle between the mandible ramus and the mandible was had become larger, the cest of the mandibular bone had thus risen cranially Very little bone was left cranial to the mylohyoid ridge and the mylohyoid muscle which was still attached to the ridge, showed no active tension and was oriented vertically instead of horizontally. This change was due to severe deformation of the mandible and the fact that the tongue could not participate in this cranial shift and demanded space far below the mylohyoid line.

The implant procedure was performed under local anaesthesia that blocked only the mental nerve and the R.buccales. No mandible block was administered, in order to make sure that the $\mathrm{N}$. mandibularis remained functioning. A full thickness flap was removed from the vestibular aspect of the lower ramus ascendens to the area of the lateral incisor. The flap was prepared down to below the mental nerve, which allowed some discrete mobilisation of this nerve and hence good access for the preparation of the implant site. Alternatively a full round flap would have been an alternative way of preparing the soft tissue.

It was therefore not possible to insert the distal BOI's (EDADS 9/14 G7) into the mylohyoid ridge and the implant had to be inserted more caudally and in a mesiodistal direction. The great difficulty of this anatomical situation in the distal mandible was to ensure bicortical anchorage with the base plate being inserted far below the mylohyoid line: the lingual soft tissues made it difficult to verify the realisation of bicortical anchorage. The anterior implants (two triple-BOI implants 7G5 EDDS) gave no problem during insertion: the lingual aspect of the mandible deflected only so much as to secure the soft tissues and vessels from the instrument for the lateral osteotomy. After all implants have been placed, the flaps were sutured and the abutments were mounted. With BOI implants, the connection area between external thread of the implant and the abutment should always positioned outside of the mucosa in order to keep the mucosal penetration area thin and make use of the fact that the vertical aspects of BOI implants were polished and hence self-cleaning. This is one of the reasons why in BOI-implants, crater-like bone losses are rarely ever seen.

The pre-existing full lower denture received holes in the area of the abutments and was reinstalled. The impression was taken by using the denture as impression tray and at the same time the bite was taken against the upper denture. Analogs made from plastic were inserted into the base of the denture after taking the impression and this impression was cast. The upper denture was mounted into the articulator with silicone-putty, while the lower model was mounted with gypsum. This way it would be possible to make adaptation directly to the original upper denture where necessary. A Brosamle-type of bridge ${ }^{1}$ was choosen as a first (or permanent) prosthetical workpiece to ensure stabilisation of the implants during the healing phase and allow normal function and chewing for the patient. A metal frame from Co-Cr-Alloy was fabricated and a try 


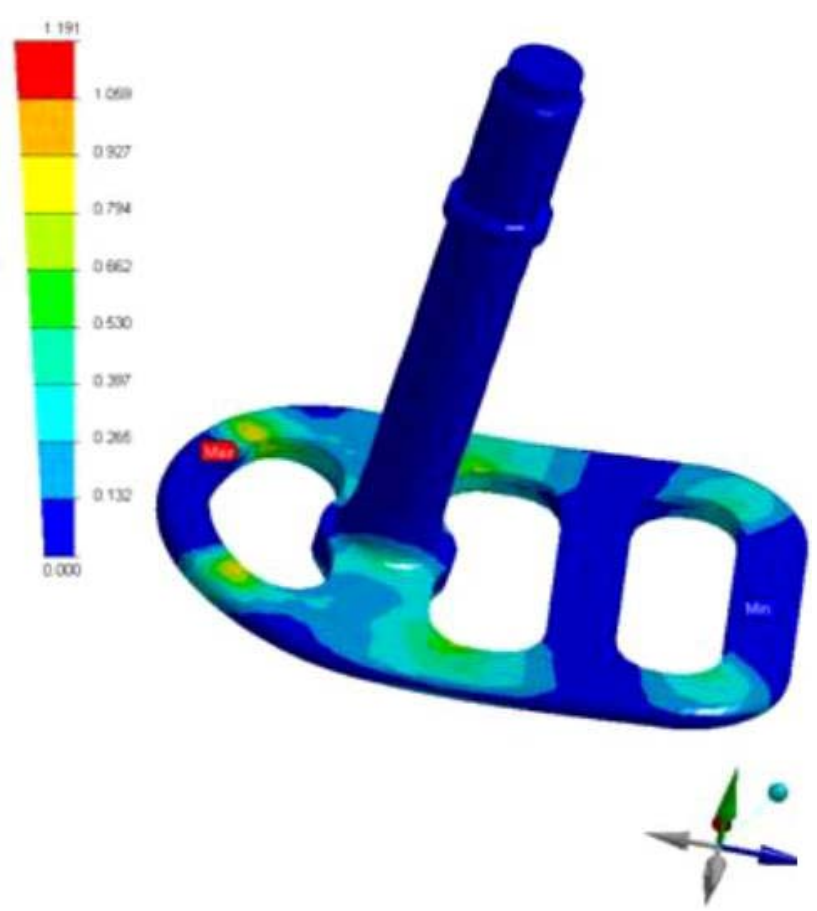

Fig. 1. FEM-analysis (Finite Element Method)

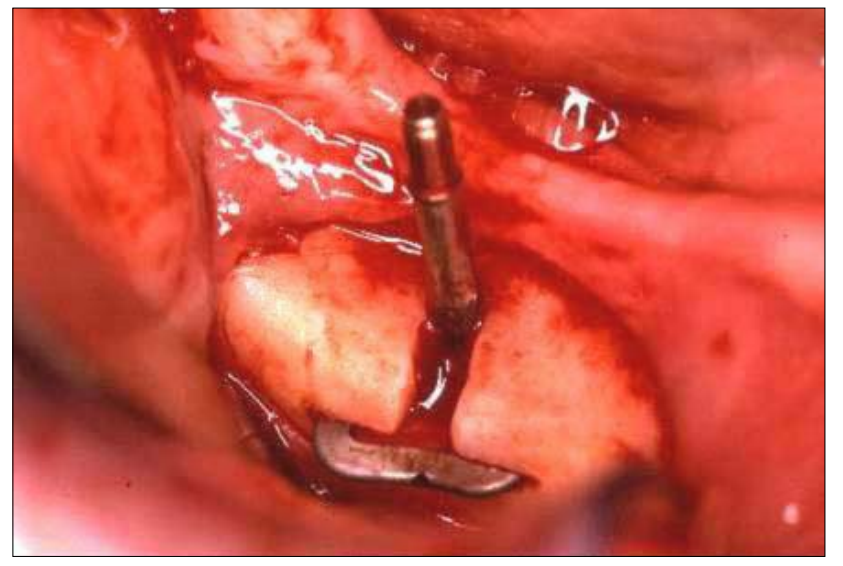

Fig. 2. Picture of Osteotomie

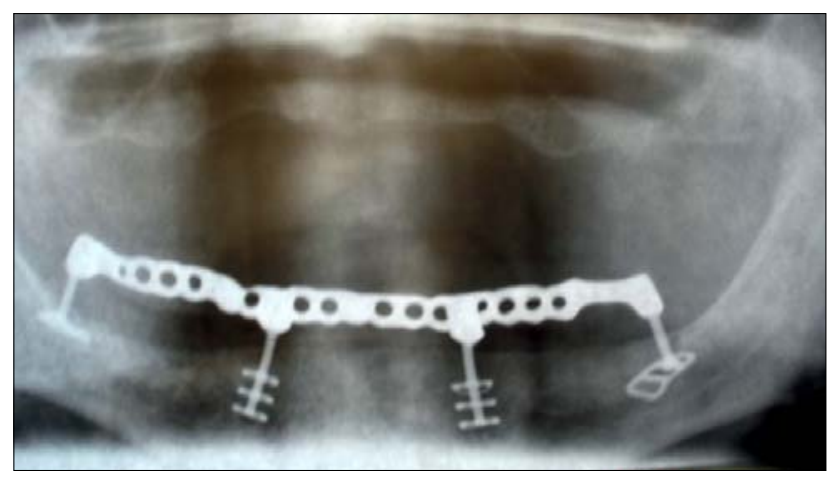

Fig. 4. OPG after Bridge cementation



Fig. 3. Insertion of Implantat

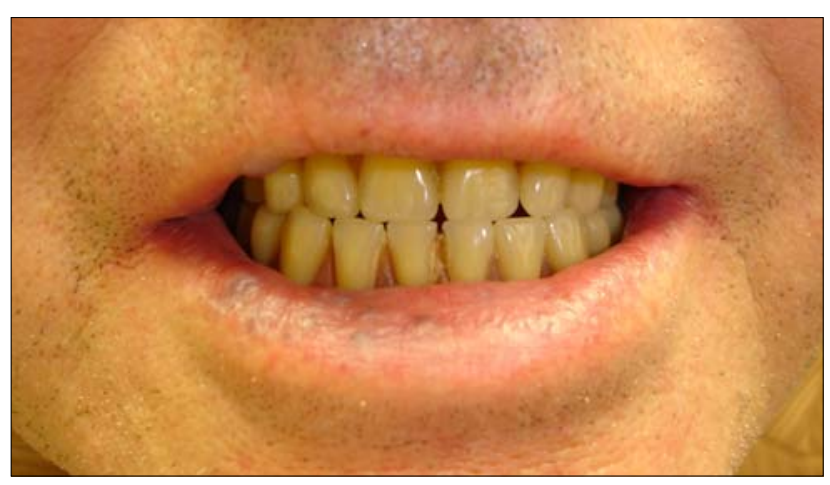

Fig. 5. Clinical visual aspect of Bridge 
in was made on the day after the implant placement. The bite, the vertical and the sagittal relationship as well as the aesthetic appearance were checked at this stage of treatment. Later on the same day this bridge was inserted and cemented with Zink-Phosphate cement (Adhesor, Dental Praha). The occlusal and masticatory situation was checked every 2-3 weeks during the first 3 months. The patient was advised not to chew any food, which could be dissected with one soft bite (no salads, steaks, hard bread) for 2 months and to take out the upper denture as often as possible in order to avoid uncontrolled nocturnal parafunctional forces and unnecessary during the daytime. In the phase of long term control was is necessary to assure that the base of the bridge did not gain contact with the crest of the alveolar bone. This contact must be expected, however, since the crestal level of bone tends to rise vertically in relation to the caudal base of the bridge ${ }^{2}$. This would cause unwanted and uncontrolled forces on the bridgework and block the mobility that counteracts flexion of the lower jaw and prevents elastic deformation of the BOI-implants. Other that crestal implants ${ }^{3}$, BOI allows elastic deformation due to their bicortical engagement in the bone.

This FEM-analysis (Finite Element Method) (Fig. 1) shows the peaks of inside a typical BOI implant, with bicortical engagement on the left and right side being assumed. Note that the flexion of the implant takes place during closing and opening of the mouth, leading to intruding and extruding forces. Under these conditions bone shows less resistance against tension than against compression $^{19}$; BOI with more than one base plate tend to be less flexible. Also the number of implants per jaw will decide over the question, whether the implant-prosthetical system behaves isoelastically or more rigidly than the property of the bone after healing and mechanical adaption.

Figures 2-5 show our clinical way of treatment and the excellent patient's compliance.

\section{DISCUSSION}

Keeping a defined and balanced prosthetical situation is necessary especially when treating with few BOI implants per jaw only. The main reasons can be summarized as follows:

- Only when a bilaterally identical anterior AFMP-angle (Planas' Masticatory Functional Angles) is present, the chewing activity of the patient will be equal on both sides ${ }^{15}$

- Only if balance is present on both sides of the distal mandible will the development of preferred chewing side is avoided. Otherwise the side, which is balanced during regular chewing, will be preferred sooner or later.

- Unilateral chewing will change the distribution of 0 - and 1-areas, creating tension pressure zones with lower mineralization in the crestal aspect of the non working side and pressure zones on the opposite site; this gradually changes the outer shape of the facial bones $^{7,13}$

- In the first healing phase after implant placement extensive remodelling takes place over the whole mandibula ${ }^{4}$. Therefore the strength of this bone is reduced for a considerable time period and unilateral functions will quickly result in morphological changes (22) that are difficult to reverse. One of the reasons for the overall remodelling is, that fatigue microdamage accompanying the remodelling will also occur in areas far away from the actual implant osteotomy ${ }^{14}$.

The idea of installing a "normal" occlusal relationship without changing the skeletal parameters of the skull is accepted today, since the long term results of surgical skeletal changes are questioned. Since the bone morphology will always adapt to the functional state, relapse after surgical corrections of Class III relationships are frequent, unless soft tissues and muscles are also reduced ${ }^{5,6,11}$.

Patients are eagerly requesting early results in implant treatments. The mainstream in dental industry today seeks to improve the implant surfaces to allow immediate load procedures. The successes of this approach is limited, if the vertical bone supply is limited. Implants inserted offers significantly more mechanical retention than conventional screw designs. Another advantageous features are the thin vertical implant part, which reduces the risks of infection significantly. The penetration area of BOI does not necessarily conincide with the area of the clinical crown as it usually does in crestal implants having diameters of more than approx. $2 \mathrm{~mm}$. This way the available bone may be used instead of bone grafting. This significantly lowers treatment costs and the necessary treatment-time und chair-time. We estimate, that in average cases the savings will be $50 \%$.

\section{CONCLUSION}

The installation of BOI implants today is a routine procedure. The philosophy of this treatment differs from conventional implantological thinking, since the possibility of mounting prostheses does not depend on the presence of vertical bone, alveolar bone or the presence of bone in the area of the desired tooth. However, sometimes aesthetical and phonetical problems have to be addressed in a different manner. Bridges made from acrylic mounted on frameworks of CoCr-Alloy which are based in BOI implants are one of the cheapest ways to meet the patients demands for fixed teeth. Since it is task of academic research to investigate and provide achievable means of establishing balanced, healthy oral function, further engagement in the BOI technique seems advisable.

\section{REFERENCES}

1. Ihde S. (2004) Principles of BOI; Chap. 11.2, Springer Verlag Berlin Heidelberg, ISBN 3-540-21665-0. 
2. Ihde S. (2003) Adaptations fonctionelles de la hauteur de l'os periimplantaire après implantation de BOI dans la mandibule. Implantodontie 12, 23-33.

3. Richter EJ. (1986) Ein Beitrag zur Erläuterung des Begriffs "Stossdämpfung” in der Implantologie. Z Zahnärztl Implantol 2, 270 273.

4. Atkinson PJ, Powell K, Woodhead C. (1977) Cortical structure of the pig mandible after the insertion of metallic implants into alveolar bone. Archs Oral Biol 22, 383-391.

5. Fischer-Brandies E. (1985) Zur Definition des Rezidivs nach operativer Progenie. Dtsch Z Mund Kiefer Gesichtschir 9, 360-366.

6. Grimm G, Breitlich E. (1961) Kritische Bewertung der Operationsergebnisse von 191 Progeniefällen unter besonderer Berücksichtigung des Verfahrens von Obwegeser/DalPont. Dtsch Zahn Mund Kieferheilk 61, 295-313.

7. Hylander WL. (1979) The functional significance of primate mandibular form. J Morphol 160, 223-240.

8. Ihde S. (1999) Fixed prosthodontics in skeletal Class III patients with partially edentulous jaws and age related prognathism: The basal osseointegration procedure. Implant Dentistry 8, 241-246.

9. Ihde S. (2003) Adaptations fonctionelles de la hauteur de l'os periimplantaire après implantation de BOI dans la mandibule. Implantodontie 12, 23-33.

10. Ihde S. (2004) Principles of BOI; Chap. 11.2, Springer Verlag Berlin Heidelberg, ISBN 3-540-21665-0.

11. Jatuporn B. (1981) Zur Rezidivtendenz nach Progenie-Operationen. Dissertation, Med. Univ. Munich/Germany.
12. Julliet JM. (1972) L'implant tridimensionnel. Inform Dent 53, 27-31.

13. Korioth TWP, Hannam AG. (1994) Deformation of the human mandible during simulated tooth clenching. J Dent Res 73, 5666.

14. Martin RB, Burr DB. (1982) A hypothetical mechanism for the stimulation of osteonal remodelling by fatigue damage. J Biomechanics $15,137-139$.

15. Planas P. La réhabilitation neuro-occlusale. Masson, Paris, 1982.

16. Richter EJ. (1986) Ein Beitrag zur Erläuterung des Begriffs "Stossdämpfung” in der Implantologie. Z Zahnärztl Implantol 2, 270273.

17. Scortecci G. (1988) L'implant dentaire tricortical. Thesis, Fac. Odont. de Marseille.

18. Scortecci G. (1999) Immediate function of cortically anchored disk-design implants without bone augmentation in moderately to severely resorbed completely edentulous maxillae. J Oral Implantol 25, 70-79.

19. Spahn FP. (1977) Untersuchungen zu einem T-förmigen Implantat für die orale Implantologie, Med. Diss. RWTH Aachen.

20. Spahn FP. (1992) Verlaufstudie: implantatbelastete Oberkieferaugmentationen mit Disk-Implantaten. Zahnärztliche Praxis 43, $438-445$.

21. Spahn FP. (1992) Zwei Jahrzehnte in Funktion - sofort belastbarer Oberkieferzahnersatz auf tridimensionalen Implantaten. Zahnärztliche Praxis 43, 321-328.

22. Wolff J. (1986) Das Gesetz der Transformation der Knochen. Verlag Aug. V Hirschwald, Berlin. 